SHS Web of Conferences 7, 01001 (2014)

DOI: $10.1051 /$ shsconf / 20140701001

C) Owned by the authors, published by EDP Sciences, 2014

\title{
Research on Features of Saving Behavior for Migrant Worker -- Based on comparison and analysis of investigation data in three places
}

\author{
Wu Wenfeng \\ School of Economics \& Management, Southwest Jiaotong University, 610031 Chengdu, China
}

\begin{abstract}
This article investigated the migrant workers in Shenzhen, Dongguan, Zhongshan, Chengdu, Xiamen areas by questionnaires. The article explores the savings behavior characteristics of migrant workers by the data analysis. With the Econometrics model which investigated the essential factor of the degree and provided policy recommendations.
\end{abstract}

Keywords. migrant worker; behavior of savings; essential factor

\section{Introduction}

Since 1978, China has realized reform and open-up policy, started modernization and industrialization programs and ushered in social transformation period in which China was transformed from agricultural society to industrial society, from planned economy to market economy, leading to formation of binary economic systems independently for urban and rural areas. In the marketization background, there was a possibility that people change their lives by adjusting their selections. Several work forces in rural area began to leave their lands to seek job in the city, resulting in emergence of migrant workers in the urban area. Migrant workers refer to the people that have agricultural account and work in the local township and village enterprises or seek jobs in towns. They are special products of township and village binary systems in China, and also unique social groups emerging in the special historical period of our country. Migrant workers are different in broad and narrow senses: The migrant workers in broad sense comprise two parts, one of which refers to rural work forces that work in local township and village enterprises within their hometowns, and the other refers to rural work forces that seek jobs of secondary or tertiary industry in towns outside their hometowns; The migrant workers in narrow sense mainly refers to the latter part (Research Group of Research Office of the State Council, 2006). The "migrant workers" analyzed in this article mainly refer to trans-regional rural work forces that seek jobs in the urban area, i.e. migrant workers in narrow sense. As residual assets, savings are the important source of investment. Migrant workers are production operators and consumers as well, and the difference from urban residents in relation to economic functions determines the particularity of their economic behaviour. With the change of closely related systems for migrant workers since the reform and opening up period, the savings behavior for rural residents changed accordingly. Therefore research on savings behavior for migrant workers becomes a primary study area of this special group. This article looks for the main factors that affect savings behavior of migrant workers, studies the general rule of their savings and seeks basis of scientific intervention in savings behaviour for migrant workers by questionnaires in cities of Shenzhen, Zhongshan, Dongguan,

This is an Open Access article distributed under the terms of the Creative Commons Attribution License 4.0, which permits unrestricted use, distribution, and reproduction in any medium, provided the original work is properly cited. 
Xiamen and Chengdu where rural migrant workers of Guangdong, Fujian and Sichuan are concentrated.

\section{Research method}

\subsection{Sampling design}

This research, based on sampling investigation, issued 500 pieces of questionnaires in Chengdu, and took back 469 valid pieces of the same. Then 270 of those pieces were analyzed exploratively using isometric random sampling, and scales were designed according to preliminary facts obtained from the investigation. Issue 100 scales for testing, conduct experimental analysis on valid scales sampled by random sampling, then revise them, three times of tests in total were performed. Investigate in a large scale if requirements were met. In the third investigation sampling, 7000 scales were issued in Chengdu, Shenzhen, Dongguan, Zhognshan and Xiamen, and 6954 valid scales were taken back, of which 1816 scales were sampled and analyzed.

\subsection{Research method}

As for detailed research method, this article firstly designs questionnaires, adopts sampling investigation to obtain corresponding analysis data, and makes statistical analysis on demography features of migrant workers in five regions to analyze the age, income details, educative income, propensity to consume according to statistical data. Finally, make analysis on influence factors of savings behavior for migrant workers in different places by regression method according to data.

\section{Sample description}

This article samples 1816 pieces of data to be analyzed through sampling investigation method, among which, male samples include 1104 persons, female samples 712 persons. Of industries in the investigation sample, construction industry of 234 persons accounts for $15.7 \%$, housekeeping industry of 84 persons for $5.6 \%$, catering industry of 230 persons for $12.7 \%$, security industry of 97 persons for $6.5 \%$, agricultural wholesale industry of 110 persons for $7.4 \%$, and other industries of 737 persons for $40.6 \%$. The average age for the samples is 31.5 , with the average location time in the investigated regions 5.5 years, average years of education 11 years and monthly income per capita 3739 yuan.

Of the investigated persons, $7.8 \%$ have resided for over one year; $70.6 \%$ have resided for less than half a year; $57.6 \%$ expressly hope to keep residing in the current work places; only $42.4 \%$ are unwilling to keep residing in the current work places. It indicates that most of the migrant workers in cities can work and reside in a relatively steady manner, and in fact have basically been an integral part of local society.

As for the ages of the investigated persons, the general average age for samples is 31.82 , in which the highest is 68 and the lowest 16. Among those samples, the average age in Guangdong is 32.19, in which the oldest investigated person is 63 , and the youngest 16 . The average age in Fujian is 31.58 , in which the oldest investigated person is 68 , and the youngest 16. The average age in Sichuan is 31.58 , in which the oldest investigated person is 61 , and the youngest 16 .

Of the education background of the investigated samples, $14.5 \%$ do not completely receive nineyear compulsory education, which in Guangdong accounts for $12 \%$, in Fujian for $16.7 \%$ and in Sichuan for $19.8 \%$. 


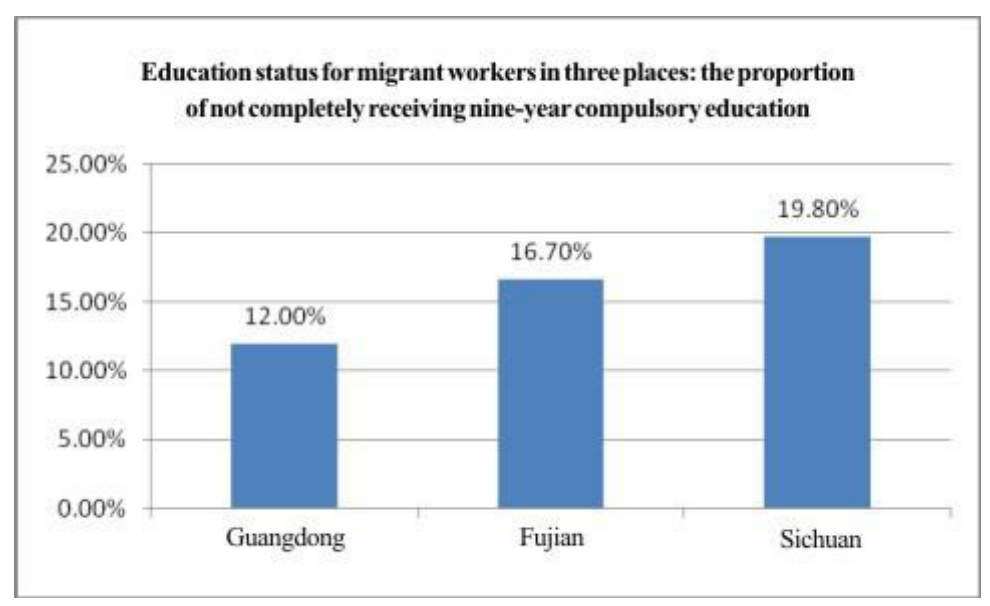

Figure 1. Education background for migrant workers in three different places

As for the occupation selecting conditions, construction industry of 234 persons accounts for $15.7 \%$, housekeeping industry of 84 persons for $5.6 \%$, catering industry of 230 persons for $12.7 \%$, security industry of 97 persons for $6.5 \%$, agricultural wholesale industry of 110 persons for $7.4 \%$, and other industries of 737 persons for $40.6 \%$. The distribution data for Guangdong, Fujian and Sichuan is seen from table 1 below:

Table 1. Sample description list

\begin{tabular}{cccc}
\hline Industry distribution & Guangdong (\%) & Fujian (\%) & Sichuan (\%) \\
\hline Construction industry & 14.5 & 20.1 & 13.1 \\
Housekeeping industry & 7.0 & 4.4 & 3.0 \\
Catering industry & 15.2 & 16.7 & 14.2 \\
Security industry & 8.6 & 3.4 & 4.5 \\
Agricultural wholesale industry & 10.6 & 4.7 & 1.1 \\
Other industries & 44.1 & 50.7 & 64.2 \\
\hline
\end{tabular}

As for the income, the average salary for the investigated persons in general samples is 3738.68 yuan, among which the salary in Guangdong region is 4111.19 yuan, and 3796.08 yuan in Fujian region, 2186.57 yuan in Chengdu region. The persons who have monthly income of less than 1000 yuan account for $1.8 \%$, and who have of above 1000 yuan account for $98.2 \%$; During the visit, it indicates that the migrant workers in cities commonly come from the low-income class and poor regions, and meanwhile the income features for different regions have been reflected.

As shown by the investigation data, the monthly average life expenditure for migrant workers of general samples is 1763.06 yuan, among which the highest amount is 40000 yuan, with the lowest only 100 yuan, and the monthly average life expenditure for migrant workers in Guangdong is 1763.06 yuan, with 1821.47 yuan for those in Fujian region and 1026.87 yuan for those in Chengdu region.

In terms of savings conditions, the average savings remaining for migrant workers of general samples is 1758.57 yuan, among which the highest amount is 25000 yuan, with the lowest 0 yuan, and the monthly average life expenditure for migrant workers in Guangdong is 1935.63 yuan, with 1820.59 yuan for those in Fujian region and 956.72 yuan for those in Chengdu region. 


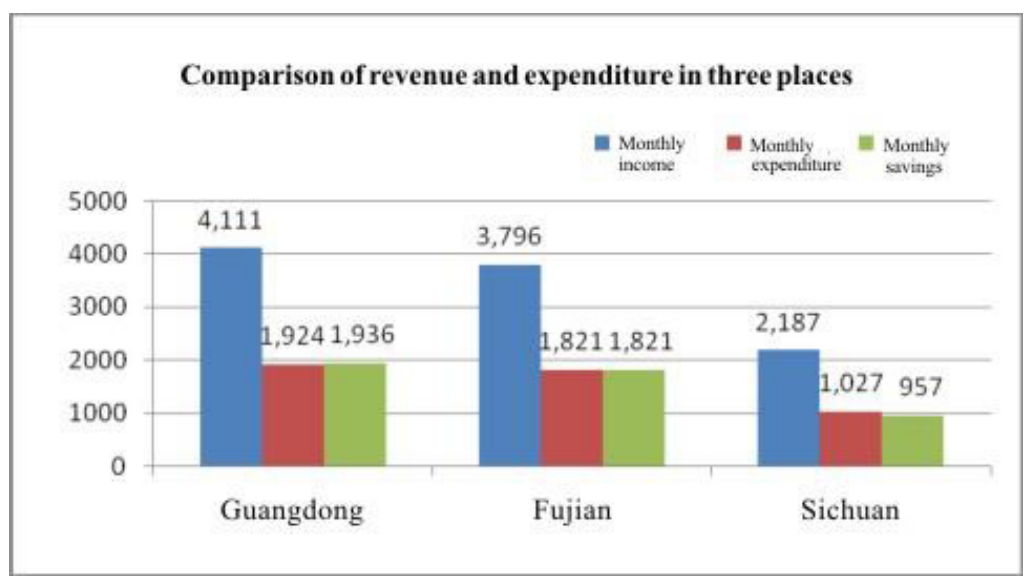

Figure 2. Expenditure for migrant workers in three different places

\section{Quantitative analysis}

\subsection{Analysis on factors that affect savings}

Savings refer to balanced difference after unit or individual income and expense accounts collect all of the incomes and expenses. There are mainly two concepts for savings based on the content it includes, i.e. gross and net savings. Gross savings is a combination of fixed assets consumption (depreciated value), capital transfer and net savings. Net savings refer to all of the remaining incomes that have not been used for current consumption and transfer payment after fixed assets depreciation is deducted from the incomes by various authorities (Liu Fangxie, 2001). In other words, as for the national income calculations and savings in economics, as long as people are willing to dispense consumer expenditure, there will be various savings for this purpose, and accumulative savings thus form the assets. The savings for residents is a flow, a remaining after the residents incomes have been used for consumption during a period; While the assets for residents is a stock, a total savings amount in a particular moment. Failing to estimate the stock assets for migrant workers in different places, this article studies the current net savings behavior for them. We assume this habit for them is unchanged in a period of time and has a relative stableness.

\subsection{The impact of age, education and gender on savings in three places}

For investigating the difference of saving habits for migrant workers of different regions, ages, education and genders, we perform a fitting of ages, education backgrounds and savings according to investigation data from early stage as in the following figures and table:

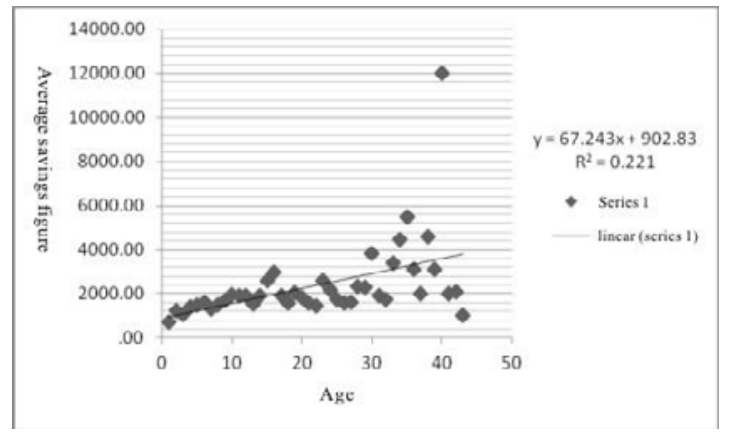

Figure 3. Age-average savings curve for general samples

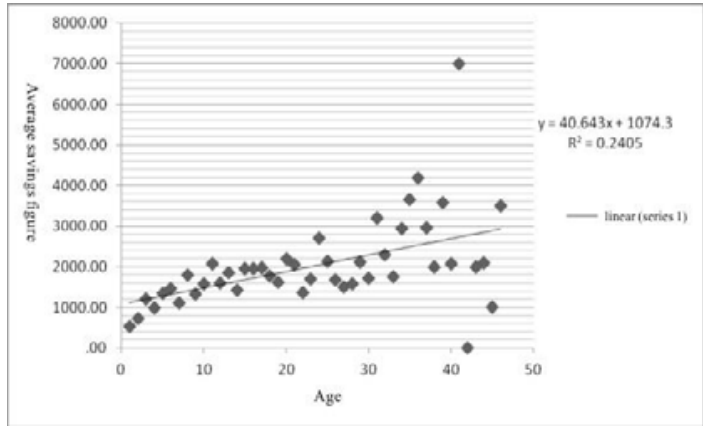

Figure 4. Age-average savings curve for Guangdong samples 


\section{ICMETM 2014}
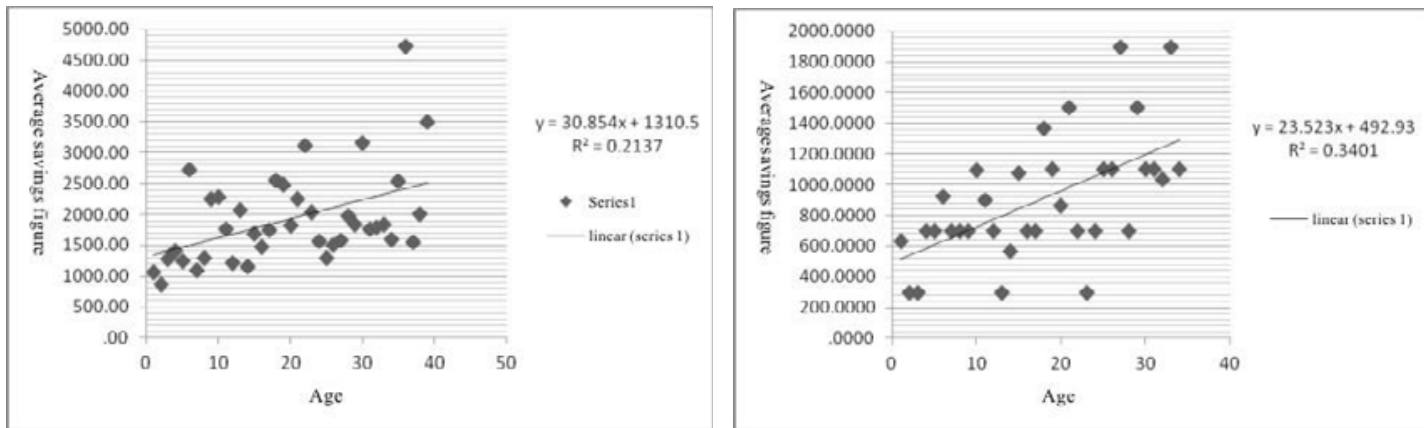

Figure 5. Age-average savings curve for Fujian samples

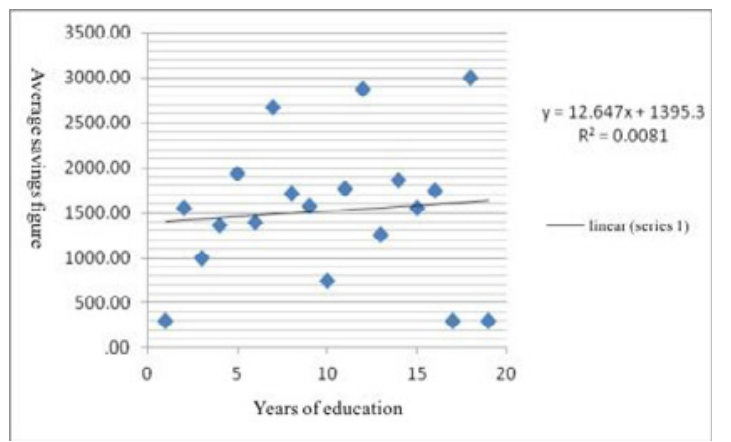

Figure 6. Age-average savings curve for Sichuan samples

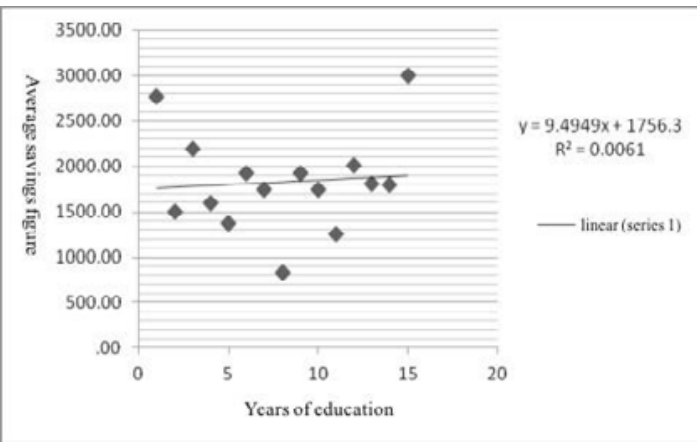

Figure 7. Education-average savings curve for general samples

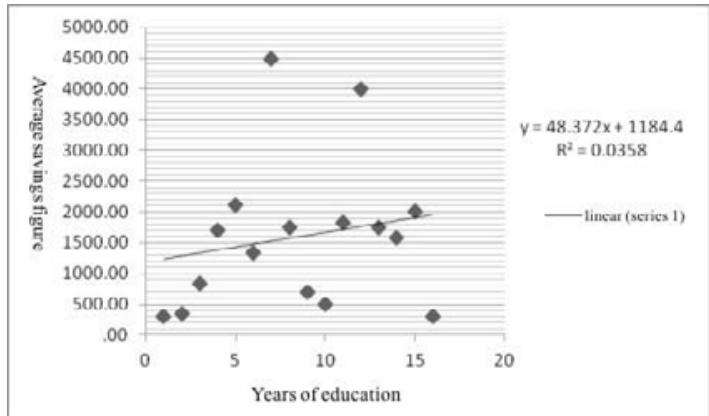

Figure 8. Education-average savings curve for Guangdong samples

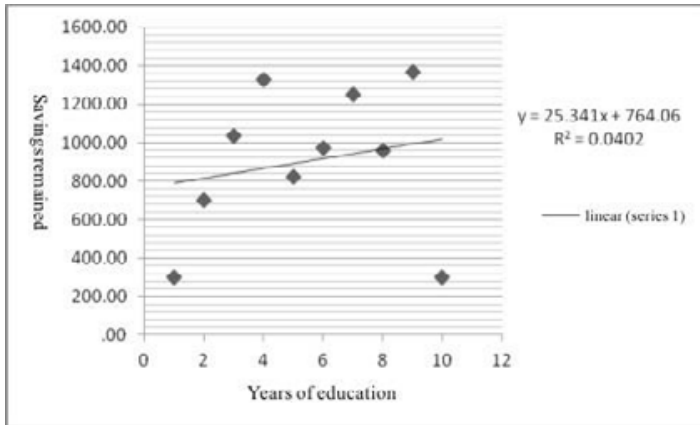

Figure 9. Education-average savings curve for Fujian samples

Figure 10. Education-average savings curve for Sichuan samples

Table 2. Difference of genders and amount of consumption

\begin{tabular}{|c|c|c|c|c|c|c|c|}
\hline \multicolumn{2}{|c|}{} & \multicolumn{2}{|c|}{ Guangdong } & \multicolumn{2}{c|}{ Sichuan } & \multicolumn{2}{c|}{ Fujian } \\
\hline \multirow{2}{*}{$\begin{array}{c}\text { Monthly } \\
\text { savings } \\
\text { average }\end{array}$} & Gender & Female & Male & Female & Male & Female & Male \\
\cline { 2 - 8 } & Average & 1648.99 & 2114.00 & 873.58 & 1011.11 & 1632.45 & 1950.17 \\
\hline
\end{tabular}




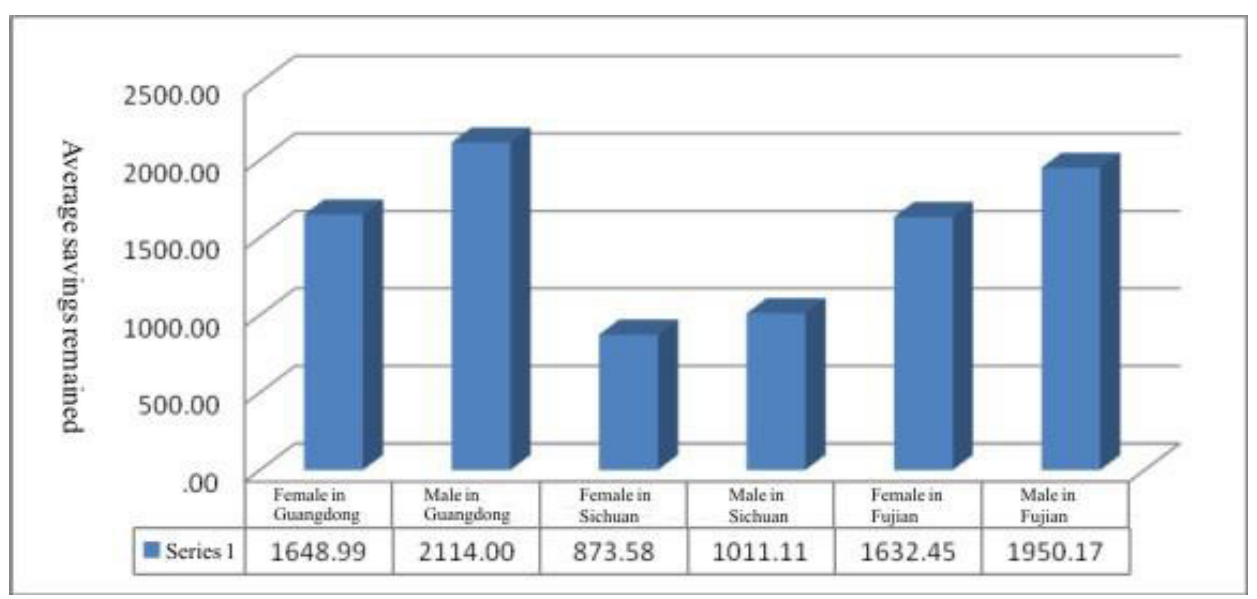

Figure 11. Difference of average savings remained for different genders in three places

As shown in the fitted figure, a positive correlation presents among education and ages of migrant workers in three places and average savings remained, which means more time of education and older in age can lead to higher tendency of savings. The tendency of savings for male is higher than that for female.

\subsection{Main factors that affect the savings behavior for migrant workers in different places}

\subsubsection{Affecting model}

For analysis on the impact of various factors on rural residents' savings, this article establishes loglinear model to study the impact of objective factors on savings behavior for migrant workers in different places. Explained variable refer to savings amount for investigated migrant workers in different places. Explanatory variable selected such factors as net income, location time, hometown returning plan, age, gender, education background, etc.. The detailed form for the model is as follows:

\section{LnSaving $=\alpha_{1} l n \_N e t i n c o m e+\alpha_{2} l n \_L o c a t i o n \_t i m e+\alpha_{3}$ Plan $+\alpha_{4}$ ln_Consumption $+\alpha$ ${ }_{5} l n \_$Education $+\alpha_{6} \ln \_$Age $+\alpha_{7} \operatorname{sex}+C$}

$\alpha$ is the flexibility of above mentioned variable to savings.

$\mathrm{C}$ is a constant term.

\subsubsection{Variable description}

If theoretically analyzed, the factors that affect savings behavior for migrant workers in different places are jointly resulted from external and internal factors. The main affecting external factors include national interest adjustment, price level change, social security, household registration system, education system, etc.. Internal factors refer to factors that can be changed and controlled by rural residents, and can directly determine the change of savings behaviour, such as income level, consumption level, consumption habit, future plan, etc. for rural residents.

Income level is one of the most important factors that determine savings behavior for migrant workers in different places. The income is a source of savings and the amount of it can determine that of savings level. There is no savings without income. The migrant workers in different places seek jobs in cities for higher income, while several migrant workers convert most of their income to savings after meeting basic life needs, to take savings as a main tool for prevention of external uncertainty. The data selected by this article takes the current income of migrant workers in different 
places during investigation period as savings variable. Under the condition of certain income, savings for migrant workers in different places determine their consumption amount. Consumption is in negative correlation to savings, and their consumption habits of migrant workers in different places can also affect the savings amount. Under the circumstance of certain income, more consumption leads to lower level of savings, and less consumption leads to higher level of savings. The data selected by this article takes the current income of migrant workers in different places during investigation period as consumption variable.

Location time and hometown returning plan are to measure stable degree of current work place for migrant workers in different places, and to reflect their sense of belonging, identity and familiarity degree with production and living environment. These variables affect the savings willingness as well as the income level and savings ability of migrant workers to a certain extent.

Education is an important factor that affects the work ability and status of migrant workers in different places, and indirectly markets their income, thus resulting in relatively great influence on their savings willingness and ability, as well as investment willingness.

The migrant workers of different ages in different places have different savings attitude and ability, as well as savings preference due to different life stages where they are.

Table 3. List of definitions of variables that affect savings behavior of migrant workers in different places

\begin{tabular}{|c|c|c|c|}
\hline Variable name & Variable meaning & $\begin{array}{l}\text { Variable economic } \\
\text { attribution }\end{array}$ & Variable definition \\
\hline Saving & $\begin{array}{l}\text { Monthly savings amount } \\
\text { for migrant workers }\end{array}$ & $\begin{array}{l}\text { Reflecting savings } \\
\text { ability for migrant } \\
\text { workers }\end{array}$ & $\begin{array}{l}\text { Cross sectional data, explained } \\
\text { variable, referring to savings amount } \\
\text { of investigation sample migrant } \\
\text { workers, with unit of yuan }\end{array}$ \\
\hline Net income & $\begin{array}{l}\text { Monthly net monetary } \\
\text { income for migrant } \\
\text { workers }\end{array}$ & $\begin{array}{l}\text { Reflecting income } \\
\text { level of migrant } \\
\text { workers }\end{array}$ & $\begin{array}{l}\text { Cross sectional data, explanatory } \\
\text { variable, referring to income data of } \\
\text { investigation sample migrant } \\
\text { workers, with unit of yuan }\end{array}$ \\
\hline Location time & Local work time & $\begin{array}{l}\text { Reflecting stable } \\
\text { degree of migrant } \\
\text { workers in work } \\
\text { regions }\end{array}$ & $\begin{array}{l}\text { Cross sectional data, explanatory } \\
\text { variable, referring to duration of } \\
\text { investigation sample migrant workers } \\
\text { in the investigation work, with unit of } \\
\text { year }\end{array}$ \\
\hline Plan & $\begin{array}{l}\text { If having hometown } \\
\text { returning plan }\end{array}$ & $\begin{array}{l}\text { Reflecting stable } \\
\text { degree of migrant } \\
\text { workers in work } \\
\text { regions }\end{array}$ & $\begin{array}{l}\text { Virtual variable data, explanatory } \\
\text { variable, referring to hometown } \\
\text { returning willingness of investigation } \\
\text { sample migrant workers }\end{array}$ \\
\hline Consumption & $\begin{array}{l}\text { Monthly net monetary } \\
\text { expenditure for migrant } \\
\text { workers }\end{array}$ & $\begin{array}{l}\text { Reflecting } \\
\text { consumption status of } \\
\text { migrant workers }\end{array}$ & $\begin{array}{l}\text { Cross sectional data, explanatory } \\
\text { variable, referring to duration of } \\
\text { investigation sample migrant workers } \\
\text { in the investigation work, with unit of } \\
\text { year }\end{array}$ \\
\hline Education & Years of education & $\begin{array}{l}\text { Reflecting quality of } \\
\text { migrant workers }\end{array}$ & $\begin{array}{l}\text { Cross sectional data, explanatory } \\
\text { variable, referring to education } \\
\text { background of investigation sample } \\
\text { migrant workers, with unit of year }\end{array}$ \\
\hline Age & Age & - & $\begin{array}{l}\text { Cross sectional data, explanatory } \\
\text { variable. }\end{array}$ \\
\hline
\end{tabular}

\subsubsection{Regression conclusion}


Table 4. Guangdong, Fujian, Sichuan data regression results

\begin{tabular}{c|ccc}
\hline \multirow{2}{*}{ Independent variable } & \multicolumn{3}{|c}{ Denpendent variable Saving $^{1}$} \\
\cline { 2 - 4 } & Guangdong & Fujiang & Sichuan \\
\cline { 2 - 4 } LN_INCOME & $1.71^{* * *}$ & $1.70^{* * *}$ & $0.88^{* * *}$ \\
LN_COMSUPTION & $-0.107^{*}$ & $-0.75^{*}$ & $-0.27^{*}$ \\
LN_LOCATION & $-0.75^{* *}$ & $-0.029^{* * *}$ & $-0.006^{*}$ \\
LN_EDUCATION & $0.007^{* *}$ & $-0.11^{* *}$ & $-0.024^{* * *}$ \\
SEX & $0.038^{* * *}$ & $0.038^{* *}$ & $0.12^{* *}$ \\
PLAN & $0.030^{* *}$ & $0.030^{* * *}$ & $0.09^{* *}$ \\
LN_AGE $^{8}$ & $-0.029^{* *}$ & $0.058^{* * *}$ & $0.31^{* * *}$ \\
C & $-0.89^{* * *}$ & $-1.38^{* *}$ & $0.76^{*}$ \\
\hline Adjusted $\mathrm{R}^{2}$ & 0.71 & 0.69 & 0.359 \\
Sample size & 475 & 1021 & 268 \\
Standard error & 0.405 & 0.409 & 0.35 \\
\hline
\end{tabular}

Note:

1. Denpendent variable Saving is savings amount for migrant workers in the investigation period.

2. Independent variable LN_INCOME, is current income migrant workers in the investigation period.

3. Independent variable LN_COMSUPTION, is current consumption migrant workers in the investigation period

4. Independent variable LN_LOCATION, is work time in the investigation region for migrant workers.

5. Independent variable LN_EDUCATION, is education background for migrant workers.

6. Virtual variable SEX, is gender of migrant workers.

7. Virtual variable PLAN, is whether migrant workers have hometown returning plan.

8. Independent LN_AGE, is age of migrant workers

***Indicates the regression results are remarkable in $1 \%$ level of probability

$* *$ Indicates the regression results are remarkable in $5 \%$ level of probability

* Indicates the regression results are remarkable in $10 \%$ level of probability

As a rational economic man, migrant workers in different places conduct savings behavior for the purpose of maximizing effectiveness in the limitation of personal income. In other words, it refers to the satisfaction from putting the set disposable income in the current consumption or savings, which means the maximization of effectiveness. Therefore whether the savings activities of migrant workers in different places can maximize the effectiveness comprises the basic principle for evaluating the rationality of residents' savings behavior in view of migrant workers in different places, i.e. microscopic view. From the analysis on data and observance, as for the set disposable income, the effectiveness obtained from the use of monetary unit income onto consumption configuration for migrant workers in different places will be progressively decreased as the part migrant workers in different places put into consumption increases; Similarly, as the part migrant workers in different places put into savings increases, and from the regression data of three places, it can be seen that individual income is in obviously positive correlation to savings, which passes the obviousness test in $1 \%$ and $5 \%$ level of probability. Individual consumption is in obviously negative correlation to savings, and as consumption increases, the savings level of migrant workers in different places obviously decreases. From the regression data of three places, local work time is in negative correlation to savings, so it can be foreseen that as the local work time increases, the security needs of migrant workers in different places will be decreased, and the future expectation will be clearer than those having shorter time, which will make them accustomed to city life better. The increase of living 
expenses leads to decrease of preventive savings motive. The education background and savings for migrant workers in different places are in positive correlations to those in Guangdong region, and Fujian and Sichuan is in negative correlation to different Guangdong regions, which, to a certain extent, reflects a stronger ability of savings and income for highly-educated Guangdong migrant workers in different places over the other two places. From the perspective of gender, the male migrant workers of three places are more willing to increase savings, and sample males account dominantly for $60.8 \%$, the savings willingness of males is also higher than that of females. The regression data of three places shows that the migrant workers in different places that have willingness of returning to hometown are more willing to increase savings. They tend to save, and take these savings to their hometown for construction, endowment, investment, children education, etc.. In terms of age structure, the willingness of savings for Guangdong migrant workers in different places will be decreased as their age increase, while willingness of savings for Fujian and Sichuan migrant workers in different places will be increased as their ages increase. We think that in perspective of "rational man", the migrant workers in different places make such decisions on savings amount resulting from comprehensively considering various restraining factors and integrated tradeoff. So we have reasons to believe from the microscopic view, the savings behavior for migrant workers is always reasonable.

\section{Conclusions and suggestions}

From the analysis on data of three places, the principal factor that affect savings tendency of migrant workers in different places is income. Since the economic transition, the incomes of migrant workers in different places have increased to a certain extent but at a rate generally lower than that of economic growth. The savings tendency of migrant workers in different places remains high, which is in close relation to current distribution system, education system and social security system of our country. This will require, to a certain extent, the policy maker to perform revolution of distribution system, education system and social security system with due consideration of economic development. Currently, the main income source of migrant workers in different places is labor income. In the current system, migrant workers in different places do not dare to consume without life security. Only if improvements are made to these systems can have savings tendency of migrant workers in different places decrease.

The biggest victim of binary economic structure is migrant workers in different places. It will be a long path to eliminate binary economic structure, however, it is urgent to remove the artificial system barriers. The government shall formulate systematic and effective policies in aspects of urbanization promotion to increase the income of migrant workers in different places and decrease the gap between urban and rural area.

Firstly, deeply reform rural land property system and accelerate land transfer process. As the rural lands are subject to collective ownership, peasants only have land contracted management right. Accelerate the land capitalization can change the single income situation for migrant workers in different places to a certain extent;

Secondly, deeply reform the household registration system, establish equal employment system for migrant workers in cities and create equal employment opportunities.

Thirdly, improve social security system. Under the condition of breaking of traditional welfare system and new social security system remaining to be improved, the imperfection of social security system, narrow coverage of social security and low security level are main features in economic transition period. Only if the social security system covers all of migrant workers in different places can they realize provision for the elderly, treatment for sickness and further remove of the shackles on migrant workers in different places.

\section{References}

1. Li Zhenming. Gradual Progress of Economic Transition and Resident Consumption[M]. Beijing: Economic Science Press, 2002. 
2. Hu Zhen, Song Hairong, Hu Junchang. Transition Economics[M]. Wuhan: Hubei People's Press, 2002:24.

3. Cheng Qizhi. Personal Investment in China Marketization[M]. Wuhan: Hubei People's Press, 1998:137-142.

4. Li Yan. Research on Savings Behavior for Chinese Residents[M]. Beijing: China Finance Publishing House, 1999:30.

5. Li Yining. Empirical Analysis on China Macro-economy[M]. Beijing: Peking University Press, 1992:149.

6. Jian Xuheng. Function Analysis on China Consumption[M]. Shanghai: Shanghai People's Publishing House, 1994:110-111.

7. Wang Man. Consumption and Savings Choices for Beijing Migrant Workers[J] Journal of Beijing Technology and Business University (Natural Science Edition), 2005(6):77-79.

8. Zhang Xinghua. Economic Analysis and Inspiration of Migrant Worker Consumption [J]. China Rural Economy, 1996(3):17-22.

9. Zhou Zhita. Empirical Research on the Paradox of Bumper Harvest[J]. Statistical Research, 2008(6):36-38.

10. Peng Shanmin. From Structure to Culture: Retrospect and Prospect of Consumption Research on Migrant Workers in Different Places [J]. Journal of Hunan Agricultural University (Social Science Edition), 2009(2):101-110. 